\title{
Increased tolerance of Litopenaeus vannamei to white spot syndrome virus (WSSV) infection after oral application of the viral envelope protein VP28
}

\author{
Jeroen Witteveldt ${ }^{1}$, Just M. Vlak ${ }^{1, *}$, Mariëlle C. W. van Hulten ${ }^{1,2}$ \\ ${ }^{1}$ Laboratory of Virology, Wageningen University, Binnenhaven 11, 6709 PD Wageningen, The Netherlands \\ ${ }^{2}$ Present address: CSIRO Livestock Industries, Queensland Bioscience Precinct, 306 Carmody Road, St. Lucia, Brisbane, \\ Queensland 4067, Australia
}

\begin{abstract}
It has been generally accepted that invertebrates such as shrimp do not have an adaptive immune response system comparable to that of vertebrates. However, in the last few years, several studies have suggested the existence of such a response in invertebrates. In one of these studies, the shrimp Penaeus monodon showed increased protection against white spot syndrome virus (WSSV) using a recombinant VP28 envelope protein of WSSV. In an effort to further investigate whether this increased protection is limited to P. monodon or can be extended to other penaeid shrimp, experiments were performed using the Pacific white shrimp Litopenaeus vannamei. As found with P. monodon, a significantly lower cumulative mortality for VP28-fed shrimp was found compared to the controls. These experiments demonstrate that there is potential to use oral application of specific proteins to protect the 2 most important cultured shrimp species, P. monodon and $L$. vannamei, against WSSV. Most likely, this increased protection is based on a shared and, therefore, general defence mechanism present in all shrimp species. This makes the design of intervention strategies against pathogens based on defined proteins a viable option for shrimp culture.
\end{abstract}

KEY WORDS: White spot syndrome virus · VP28 - Vaccination · Structural proteins · Litopenaeus vannamei $\cdot$ Immunology

\section{INTRODUCTION}

It has been assumed that it is not possible to protect invertebrates against pathogens using an induced (e.g. vaccination) or primed (i.e. past experiences with a pathogen) immune response. In recent years, however, many phenomenological data have suggested the existence of such adaptive immune mechanisms in invertebrates (Kurtz 2005). In the last decade, viral diseases have caused major problems in the expanding shrimp culture industry. With the increase in both the social and economical importance of shrimp culture (Lundin 1996), much research has been aimed at designing disease intervention strategies and has resulted in expanded knowledge of crustacean immunology.
In vivo experiments using Penaeus japonicus have demonstrated the presence of a quasi-immune response to white spot syndrome virus (WSSV) in which survivors of both natural and experimental infections re-challenged with WSSV showed higher survival compared to naive shrimp (Venegas et al. 2000). Moreover, haemolymph of the survivors collected $17 \mathrm{~d}$ postchallenge showed some virus neutralisation activity. Further evidence of a specific immune response in crustaceans has been found using Daphnia magna (Little et al. 2003). In the present study, maternal transmission of strain-specific immunity was demonstrated, as progeny were less likely to be infected by parasite strains to which their mothers had been challenged. The presence of immunological memory has also been 
demonstrated for the copepod Macrocyclops albidus, individuals of which were less likely to be re-infected with antigenically related lines of a natural parasite compared to less related lines (Kurtz \& Franz 2003).

However, as the above examples involve whole parasites, the enhanced immunological status might be explained by the recognition of general 'pathogenassociated molecular patterns' (e.g. lipopolysaccharide, lipoteichoic acid, mannans, glycans) by 'patternrecognition receptors' (PRRs), the effect of which has been shown in numerous studies (Duvik \& Söderhäll 1990, Söderhäll et al. 1994, Kim et al. 2000, RomeoFigueroa et al. 2004). A recent study using the overexpressed WSSV envelope protein VP28 as a subunit vaccine in Penaeus monodon shrimp was the first to show that a VP28-specific antiviral response could be triggered with a protein lacking patterns that can be recognised by known PRRs, suggesting the presence of an unknown type of immune system (Witteveldt et al. 2004a,b).

To further investigate whether this increased protection is strictly species specific or based on a more general mechanism, experiments were performed using the Pacific white shrimp Litopenaeus vannamei as an alternative host for WSSV. This species is of increasing importance in shrimp farming, as it is reported to have a lower susceptibility to WSSV compared to Penaeus monodon (Briggs et al. 2004). Nevertheless, the culture of $L$. vannamei is still greatl hampered by mass mortalities due to WSSV (International Office of Epizootics, 2005; available at: www.oie.int/ eng/info/hebdo/a_dsum.htm). In the present study, $L$. vannamei shrimp were orally fed with inactivated bacteria overexpressing VP28 and found to be tolerant to WSSV following challenge by immersion.

\section{MATERIALS AND METHODS}

Shrimp culture. Specific pathogen-free (SPF) Litopenaeus vannamei of the Kona strain (Wyban et al. 1992) were used for the experiments. Postlarvae (PL 8 to 12) from Ceatech farms (USA) were maintained at the Laboratory of Aquaculture \& Artemia Reference Centre, Ghent University. Each shipment was tested by PCR (polymerase chain reaction) for the presence of WSSV, Monodon baculovirus, yellow head virus, Taura syndrome virus and infectious hypodermal and haematopoietic necrosis virus. Prior to each experiment, shrimp of approximately $5 \mathrm{~g}$ were transferred to an experimental system located at the Laboratory of Virology at Wageningen University and stocked in 1801 aquariums, each fitted with an individual filter system (Eheim), heating (Schego) to $28 \pm 1^{\circ} \mathrm{C}$ and continuous aeration. All experiments were performed in artificial seawater (Instant Ocean, Aquarium Systems) at a salinity of approximately $20 \%$.

Feeding experiments. Groups of 10 shrimp were vaccinated by feeding food pellets coated with either VP28-expressing bacteria, bacteria containing the empty pET28a vector, or PBS (phosphate-buffered saline) for the positive and negative controls. The shrimp were vaccinated for $7 \mathrm{~d}$, followed by $7 \mathrm{~d}$ of normal food, as this incubation period showed the highest response in previous studies (Witteveldt et al. 2004b). Subsequently, all shrimp were challenged by immersion, except for 5 shrimp that received PBS-coated food pellets, which were mock infected.

Statistical analysis. Statistical analysis of the obtained time-mortality relationships was performed using chi-squared tests at a 5\% confidence level. The protection against WSSV after feeding bacteria-coated food pellets was calculated as a relative percent survival (RPS) calculated as: (1 - vaccinated group mortality/control group mortality) $\times 100$ (Amend 1981).

Unless stated otherwise, the materials and methods were similar to the procedures previously described in Witteveldt et al. (2004b).

\section{RESULTS AND DISCUSSION}

The major WSSV envelope protein VP28 was selected for use, as this protein showed an increase in shrimp survival after oral application in Penaeus monodon (Witteveldt et al. 2004b). VP28 was expressed fused to a (HIS) $)_{6}$-tag and without its N-terminal hydrophobic domain. An empty pET28a vector was used as negative control. Expression of the proteins was checked through SDS-PAGE (sodium dodecyl sulphate polyacrylamide gel electrophoresis) and confirmed by Western analysis using anti-WSSV polyclonal antiserum to be of viral origin (Witteveldt et al. 2004b).

The cumulative mortalities of the titration of WSSV in Litopenaeus vannamei are shown in Fig. 1. A final cumulative mortality of $100 \%$ was observed when shrimp were incubated with $9 \mu \mathrm{l}$ WSSV stock shrimp ${ }^{-1}$. Incubation with 3 and $6 \mu$ stock shrimp ${ }^{-1}$ resulted in final cumulative mortalities of $75 \%$, although $3 \mu \mathrm{l}$ showed a delay in the onset of mortalities. Incubation with $1 \mu \mathrm{l}$ resulted in a slightly lower cumulative mortality $(67 \%)$. Based on this titration, a challenge pressure of $6 \mu \mathrm{l}$ of WSSV stock shrimp ${ }^{-1}$ was selected for the experiment.

Two groups of Litopenaeus vannamei shrimp were vaccinated by feeding for $7 \mathrm{~d}$ with food pellets coated with bacteria containing pET28a-VP28 and pET28a (control). Two other groups of shrimp received PBScoated food pellets. After the $7 \mathrm{~d}$ period, all shrimp received normal food for another period of $7 \mathrm{~d}$. Subse- 


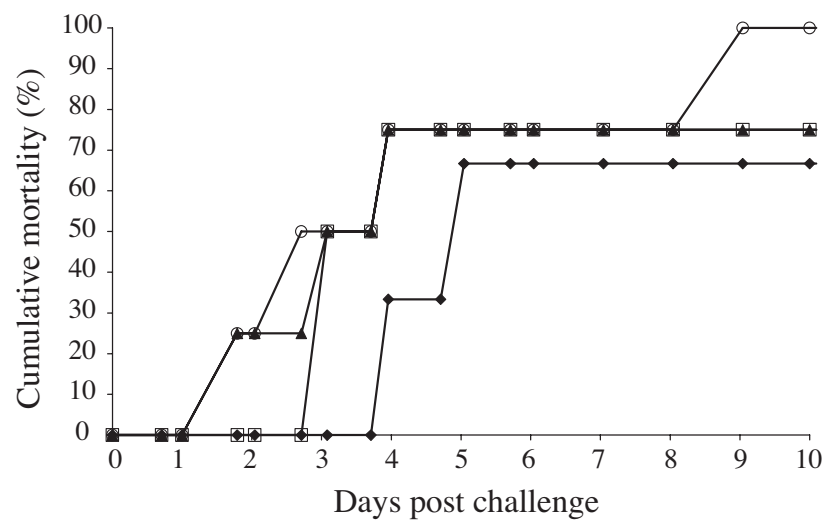

Fig. 1. Litopenaeus vannamei. Time-mortality relationship of L. vannamei challenged with 4 different white spot syndrome virus (WSSV) dilutions. Cumulative mortality rates of shrimp challenged with $1 \mu \mathrm{l}(\bullet), 3 \mu \mathrm{l}(\square), 6 \mu \mathrm{l}(\bullet)$ and $9 \mu \mathrm{l}$ $(\odot)$ of WSSV stock shrimp ${ }^{-1}$ are plotted against the days after challenge

quently, the VP28, pET28a and positive control groups were challenged by immersion using $6 \mu \mathrm{l}$ WSSV stock shrimp $^{-1}$. At the same time, the negative control was mock challenged. The resulting time-mortality relationship is shown in Fig. 2. The shrimp vaccinated with VP28 showed a significantly lower cumulative mortality (RPS value of $50 \%$ ) compared to both the pET28afed shrimp and the positive control. All shrimp that died during the experiment tested positive, and all surviving shrimp tested negative for WSSV by 1-step PCR (Witteveldt et al. 2004b).

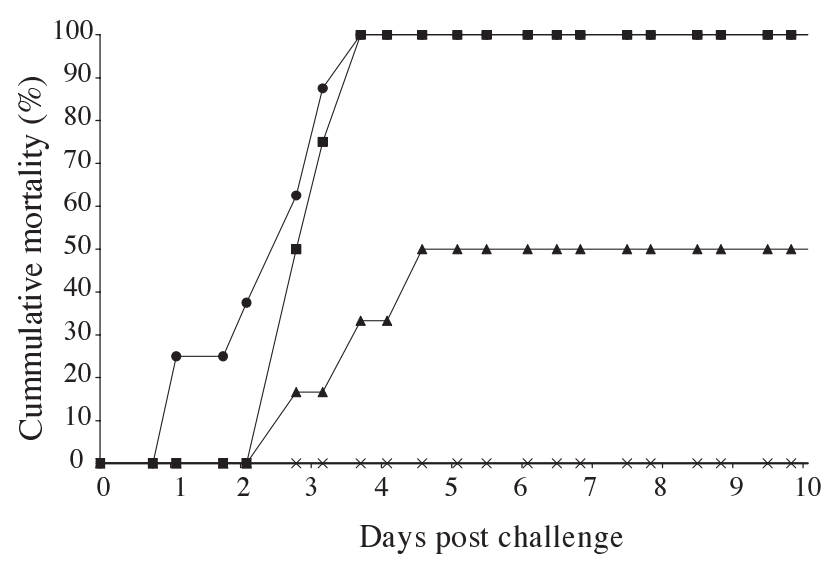

Fig. 2. Litopenaeus vannamei. Time-mortality relationship after feeding bacteria-coated food pellets and challenge of $L$. vannamei. Cumulative mortality rates of shrimp from the experimental groups VP28 $(\boldsymbol{-}-)$, pET28a $(-\mathbf{-})$, positive control $(-)$ and negative control $(-)$ are plotted against the days after challenge. The VP28-vaccinated group shows a significantly lower $(\mathrm{p}<0.05)$ cumulative mortality compared to both the pET28a and positive control groups
The $7 \mathrm{~d}$ interval period between the last bacteriacoated pellet feeding and the challenge was chosen as this resulted in the highest level of protection of Penaeus monodon (Witteveldt et al. 2004b). The level of protection in Litopenaeus vannamei was lower compared to $P$. monodon (RPS values of $50 \%$ in L. vannamei and $77 \%$ in $P$. monodon when comparing the VP28 to the pET28a groups), but was comparable to other trials in $P$. monodon using a similar, high, challenge pressure (authors' unpubl. results).

This study has shown that the enhanced tolerance of Penaeus monodon to WSSV upon oral application of VP28 can also be induced in Litopenaeus vannamei. Although the experiments do not address the mechanism of the observed protection, they do suggest that the effect is based on a general and probably novel type of immunological mechanism conserved among shrimp species. Molecular analysis of the host response to VP28 application, as a first step in revealing this mechanism, is in progress.

Increased protection using the WSSV envelope protein VP28 has now been demonstrated in 2 of the most important shrimp species in aquaculture, Penaeus monodon and Litopenaeus vannamei. Most likely, similar results could be obtained for other shrimp species, underlining the value of vaccination strategies to assist the shrimp farming industry in the battle against viral and bacterial diseases. Furthermore, these results make the design of intervention strategies against pathogens based on defined proteins a viable option for a healthy shrimp culture.

Acknowledgements. We thank A. M. G. Vermeesch for her technical assistance and M. Wille and J. de Smyter of the Laboratory of Aquaculture \& Artemia Reference Centre, Ghent University, Belgium, for kindly providing the shrimp. This research was supported by Intervet International BV, Boxmeer, The Netherlands.

\section{LITERATURE CITED}

Amend DF (1981) Potency testing of fish vaccines. In: Anderson DP, Hennessen W (eds) Fish biologics: serodiagnostics and vaccines. S. Karger, Basel, p 447-454

Briggs M, Funge-Smith S, Subasinghe R, Philips M (2004) Introduction and movement of Penaeus vannamei and Penaeus stylirostris into Asia and the Pacific. Food and Agriculture Organization of the United Nations, Regional Office for Asia and the Pacific, Bangkok. RAP Publ. 2004/10

Duvic B, Söderhäll K (1990) Purification and characterization of $\beta$-1,3-glucan-binding protein from the plasma of the crayfish Pacifastacus leniusculus. J Biol Chem 265:9332-9337

Kim YS, Ryu JH, Han SJ, Choi KH and 5 others (2000) Gramnegative bacteria-binding protein, a pattern recognition receptor for lipopolysaccharide and $\beta$-1,3-glucan protein that mediates the signaling for the induction of innate immune gene in Drosophila melanogaster cells. J Biol Chem 275:32721-32727 
Kurtz J (2005) Specific memory within innate immune systems. Trends Immunol 26:186-192

Kurtz J, Franz K (2003) Innate defence: evidence for memory in invertebrate immunity. Nature 425:37-38

Little TJ, O'Connor B, Colegrave N, Watt K, Read AF (2003) Maternal transfer of strain-specific immunity in an invertebrate. Curr Biol 13:489-492

Lundin GG (1996) Global attempts to address shrimp disease. Marine/Environmental Paper No. 4, Land, Water and Natural Habitats Division, Environment Department, The World Bank, Rome

Romeo-Figueroa MG, Vargas-Requena C, Sotelo-Mundo RR, Vargas-Albores F, Higuera-Ciapara I, Söderhäll K, YepizPlascencia G (2004) Molecular cloning of a $\beta$-glucan pattern-recognition lipoprotein from the white shrimp Penaeus (Litopenaeus) vannamei: correlations between the deduced amino acid sequence and the native protein structure. Dev Comp Immunol 28:713-726

Söderhäll K, Cerenius L, Johansson MW (1994) The prophenoloxidase activating system and its role in invertebrate

Editorial responsibility: Timothy Flegel,

Bangkok, Thailand defence. Ann NY Acad Sci 712:155-161

Venegas CA, Nonaka L, Mushiake K, Nishizawa T, Murog K (2000) Quasi-immune response of Penaeus japonicus to penaeid rod-shaped DNA virus (PRDV). Dis Aquat Org 42: 83-89

Witteveldt J, Vlak JM, van Hulten MCW (2004a) Protection of Penaeus monodon against white spot syndrome virus using a WSSV subunit vaccine. Fish Shellfish Immunol 16:571-579

Witteveldt J, Cifuentes CC, Vlak JM, van Hulten MCW (2004b) Protection of Penaeus monodon against white spot syndrome virus by oral vaccination. J Virol 78:2057-2061

Wyban JA, Sweeney JN (1991) The Oceanic Institute shrimp manual: intensive shrimp production technology. The Oceanic Institute, Makapu'u Point, Waimanalo, HI

Wyban JA, Swingle JS, Sweeney JN, Pruder GD (1992) Development and commercial performance of high health shrimp using specific pathogen free (SPF) broodstock Penaeus vannamei. In: Wyban JA (ed) Proc Spec Session Shrimp Farming, May 22-25, 1992, Orlando. World Aquaculture Society, Baton Rouge, LA, p 254-260

Submitted: August 12, 2005; Accepted: November 7, 2005 Proofs received from author(s): April 12, 2006 